\title{
Ras Association Domain-Containing Protein 7
}

National Cancer Institute

\section{Source}

National Cancer Institute. Ras Association Domain-Containing Protein 7. NCI Thesaurus. Code C158519.

Ras association domain-containing protein 7 (373 aa, $40 \mathrm{kDa}$ ) is encoded by the human RASSF7 gene. This protein plays a role in the inhibiting the activation of c-Jun $\mathrm{N}$-terminal kinases (JNK) by dual specificity mitogen-activated protein kinase kinase 7 (MAP2K7), which prevents JNK-dependent apoptosis. 